Sir Alexander Russell, Dr. P. Stocks and Dr. J. G. Thwaites. The secretary of the Royal Commission and of the three committees is Mr. N. F. MeNicoll, of the Ministry of Health.

The terms of reference of the Royal Commission are to examine the facts relating to the present population trends in Great Britain; to investigate the causes of these trends and to consider their probable consequences; to consider what measures, if any, should be taken in the national interest to influence the future trend of population; and to make recommendations.

\section{Lavoisier Statue in Paris}

Accondnge to the July 1943 issue of the French monthly philatelic review, L'Echangiste Universel, a copy of which has just reached Great Britain, a 4-franc postage stamp is being issued in commemoration of Lavoisier, the centenary of whose birth occurred on August 26, 1943 (see Nature, Aug. 21, 1943 , p. 207). Incidental reference is made to the removal "depuis un an" of the bronze statue of Lavoisier which stood at the north end of the Madeleine, not far from his town house (now re. built), 17 Boulevard de la Madeleine. L'Echangiste Universel appears to have no doubt about the fate of this superb monument-the work of Barrias-for its removal is attributed, with tactful obliquity, to the "service de la récupération des métaux", and the comment is added: "Pauvre Lavoisier connut à deux réprises, les vicissitudes de l'exécution capitale".

It will be remembered that Barrias adorned the pedestal of this beautiful work of art with two bronze reliefs, one of which depicted Lavoisier at work in his laboratory with Madame Lavoisier, his capable and devoted assistant, who is said to have learnt English so that she might translate for her husband the scientific papers of his great contemporaries, Cavendish and Priestley. In the other panel could be seen Lavoisier lecturing before the Paris Academy of Sciences, with Lagrange, Monge, Lamarck, Condorcet and Laplace among his audience. Though the pedestal was standing when $L^{\prime}$ Echangiste Universel recorded the destruction of the statue, the activities of the "service de la récupération des métaux" in occupied countries would seem to indicate that Barrias' bronze panels, with the statue, may never be seen again.

\section{New Mathematical Tables}

The many users and admirers of the New York Work Projects Administration Mathematical Tables always studied the impressive list at the end of each volume of further tables to be published, and looked forward to the time when much-needed values would be available. It was a great shock to them when President Roosevelt announced, towards the end of 1942, that all W.P.A. activities were to cease; it was hard to realize that such a great international asset as the wonderful New York team of computersthe greatest the world has ever known-was to be destroyed at a time when its proved usefulness might have been diverted to the war effort. Actually, although the greater part has been disbanded, a nucleus hais remained in being to help the Service departments, under the sponsorship of the U.S. Bureau of Standards. Naturally there were, early in 1943 , a great number of tables ready for press, but not printed. It is with feelings of relief that we learn that the publication of these has now been provided for, and that four volumes have been announced already. The first gives reciprocals of the integers from 100,000 to 200,000 , and thus extends the tables of Oakes (now unobtainable) and Cotsworth, which stop at 100,000 . The second is a 10-place table of the Bessel functions $J_{0}(z)$ and $J_{1}(z)$ for complex arguments, giving real and imaginary parts for $\varphi=0\left(5^{\circ}\right) 90^{\circ}$ and a range $0(0 \cdot 01) 10$ of the modulus. The third table gives circular and hyperbolic tangents and ootangents to eight significant figures for $x=0(0.0001) 2$; it is thus a companion to the similar values of sines and cosines that appeared in 1939. The American practice of computing by calculating machines led to a revival some fifteen years ago of the Lagrangian interpolation formula. The new tables now provided give the coefficients for interpolating with any number of points (that is, tabular values) from 3 to 11 . Incidentally, they include all the coefficients of Everett's central difference formula. The tables are to be issued by the Columbia Press, Ithaca, N.Y. (in Great Britain by Scientific Computing Service, Ltd., 23 Bedford Square, London, W.C.1).

\section{British Medical Bulletin}

Is 1940 the Medical Research Council, the Ministry of Information and the editorial department of the British Medical Association decided to send abroad abstracts of important articles in British medical journals, and Dr. Howard Jones was appointed to do this work under the direction of the editor of the British Medical Journal. By the end of 1941 a British Medical Information Service had been formed, and the British Council, which had supported the work from its inception, took it over as a permanent part of its work. The British Medical Bulletin is published in English, Turkish, Portuguese and Spanish, and Dr. Howard Jones, who is now a whole-time officer of the British Council, has made it a valuable addition to medical literature.

\section{One Hundred Years at the Cincinnati Observatory}

EvERETT L. YowkL has an interesting article with the above tjtle in Sky and Telescope $(3$, No. 2 ; December 1943). He gives an account of the development of the Observatory from the days when Ormsby MacKnight Mitchel resigned his professorship of mathematics, engineering and mechanics at Cincinnati College, and later, in the spring of 1842, started giving lectures on astronomy. These lectures were so well received that Mitchel announced his intention of building and equipping an observatory; and immediately he solicited membership for a society, each member to subscribe for a share at 25 dollars. It is remarkable that in spite of many initial difficultieslack of funds in particular-Mitchel began the erection of the building with one carpenter and one mason as foremen, and on November 9, 1842, ex-President John Quincy Adams, then in his seventy-seventh year, laid the corner stone. In January 1845 the 11-inch refractor which Mitchel had purchased in Munich arrived; it was mounted in the spring of the same year.

As the Observatory was without endowment, Mitchel agreed to act as director for ten years without remuneration. Unfortunately, he had to devote a lot of time to lecturing at the College, which provided his only means of livelihood, and in consequence he 